\title{
The gene for $\gamma$-glutamylcysteine synthetase from Thiobacillus ferrooxidans has low homology to its Escherichia coli equivalent and is linked to the gene for citrate synthase
}

\author{
Rosamund Powles, Shelly Deane and Douglas Rawlings \\ Author for correspondence: Douglas Rawlings. Tel: +2721650 3261. Fax: +27216504023. \\ e-mail : doug@molbiol.uct.ac.za
}

Department of Microbiology.

University of

Cape Town,

Rondebosch 7700 ,

South Africa

\begin{abstract}
The gene for $\gamma$-glutamylcysteine synthetase (gshA) from Thiobacillus ferrooxidans was isolated from a family of cosmids by its ability to complement an Escherichia coli gshA trxA double mutant which was unable to grow on minimal medium lacking glutathione. The predicted sequence of the $\gamma$ glutamylcysteine synthetase was found to have only $18 \%$ amino acid sequence identity to the equivalent enzyme from $E$. coli. In spite of this low sequence homology, concentrations of GSH in a cell extract prepared from the $E$. coli gshA trxA mutant containing the cloned gene were almost as high as in a cell extract prepared from a wild-type $E$. coli strain. The gshA gene was found to be physically and transcriptionally linked to the $T$. ferrooxidans gene for citrate synthase (g/tA). The $T$. ferrooxidans and $E$. coli citrate synthases shared $37 \%$ amino acid sequence identity and the cloned $T$. ferrooxidans citrate synthase gene was able to complement an $E$. coli gltA mutant.
\end{abstract}

Keywords: Thiobacillas ferrooxidans, $\gamma$-glutamyicysteine synthetase, citrate synthase, molecular cioning

\section{INTRODUCTION}

Thiobacillus ferrooxidans is an autotrophic, $\mathrm{N}_{2}$-fixing,

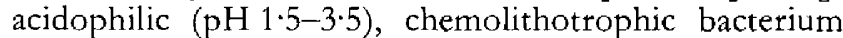
which obtains its energy from the oxidation of either $\mathrm{Fe}^{2+}$ to $\mathrm{Fe}^{3+}$ or reduced forms of sulphur to sulphate. There has been much interest in $T$. ferrooxidans because of its use in industrial mineral processing and because of its unusual physiology.

During the commercial biooxidation of a mineral such as arsenopyrite, large quantities of air are pumped into the reactor vessels and the redox potential of the solution may rise from less than $+300 \mathrm{mV}$ before oxidation to greater than $+700 \mathrm{mV}$ when oxidation is complete (Lindström et al., 1992). This implies that the organism must have considerable redox-controlling capacity and the ability to withstand the toxic effects of oxygen. Glutathione is one of the major low-molecular-mass thiol components of nearly all cell types and is involved in the control of redox status and is a scavenger of free radicals. Other gluta-

The GenBank accession number for the sequence reported in this paper is L75931. thione-associated intracellular functions include its role in transpeptidation reactions, in the reduction of protein thiol groups and as an enzyme cofactor in DNA synthesis (Meister \& Anderson, 1983).

Glutathione synthesis takes place in two ATP-dependent steps. In the first, $\gamma$-glutamylcysteine synthetase catalyses the formation of the dipeptide, $\gamma$-glutamylcysteine, from L-glutamate and I-cysteine:

L-glutamate + L-cysteine + ATP

$$
\rightarrow \gamma \text {-glutamylcysteine }+\mathrm{ADP}+\mathrm{P}_{\mathrm{i}}
$$

Glycine is then added to the C-terminal site of the dipeptide to yield glutathione; this reaction is catalysed by glutathione synthetase:

$$
\begin{aligned}
\gamma \text {-glutamylcysteine }+ \text { glycine }+ & \text { ATP } \\
& \rightarrow \text { glutathione }+\mathrm{ADP}+\mathrm{P}_{\mathrm{i}}
\end{aligned}
$$

The $\gamma$-glutamylcysteine synthetase enzyme has been isolated from, and studied in, a number of organisms. The mammalian enzymes (rat and human) are composed of two subunits $(73 \mathrm{kDa}$ and $27 \mathrm{kDa})$ that can be reversibly dissociated using DTT (Seelig et al,, 1984). The heavy subunit exhibits catalytic activity and feedback inhibition 
by GSH (Seelig et al., 1984; Richman \& Meister, 1975), whereas the small subunit has been shown to have a tegulatory function (Huang et al., 1993). The $\gamma$-glutamylcysteine synthetase of Nicotiana tabacum is composed of two identical $34 \mathrm{kDa}$ subunits (Hell \& Bergmann, 1990) whereas all other $\gamma$-glutamylcysteine synthetases studied, those in yeast (Dennda \& Kula, 1986), Arabidopsis thaliana (May \& Leaver, 1994) and the bacteria Proteus mirabilis (Kumagai et al., 1982) and Eschericbia coli (Huang et al., 1988), contain a single polypeptide of approximately $60 \mathrm{kDa}$. Five of the $\gamma$-glutamylcysteine synthetase $(g s h A)$ genes have been sequenced.

We have been investigating intracellular systems that might play a role in the ability of $T$. ferrooxidans to cope with large changes in its external redox potential. Here we report the isolation of the $T$. ferrooxidans gene for $\gamma$ glutamylcysteine synthetase and its transcriptional linkage to the gene for citrate sytnthase. This is only the second $g s h A$ gene to be sequenced from a bacterium.

\section{METHODS}

Bacterial strains and plasmids. Genotypes of the strains used are as follows: E. coli JM109, $\operatorname{rec} A 1$ end $A 1$ gyr $A 96$ thi bsdR 17 supE44 relA1 $\lambda^{-} \Delta($ lac-pro $A B)\left(\mathrm{F}^{\prime}\right.$ traD36 pro $A B$ lac $\left.1^{\mathrm{q}} \mathrm{Z} \Delta \mathrm{M} 15\right)$; E. coli $\mathrm{BH} 5262 \mathrm{~K}-12, \mathrm{~F}^{-}$araD139? galU galK bsr rpsL argH1 trxA7004 gsh A srl::'Tn10; E. colt MC1061 K-12, $\mathrm{F}^{-}$araD139? gall galK hsdR rpsL; E. coli MOB150, $\mathrm{F}^{-}$glt A5 lct-1 thi-1 lac Y1 galK 2 bsdR 4 xyl-5 mtl-1 tsx-57 tfr-5 rpsL20 sup E44. E. colistrain BH5262 was kindly donated by J. A. Fuchs (University of Minnesota, USA). D. O. Wood (University of South Alabama College of Medicine, USA) provided E. coli MOB150 and plasmid pMW264. Plasmids pBluescript SK, pLCMB21 and pLCMB20 were used for subcloning and sequencing.

Media. Tetrathionate medium was made from mineral salts solution $\left(\mathrm{g} \mathrm{l}^{-1}\right)$ : $\left(\mathrm{NH}_{4}\right)_{2} \mathrm{SO}_{4}, 3.0 ; \mathrm{KCl}, 0 \cdot 1 ; \mathrm{K}_{2} \mathrm{HPO}_{4}, 0.5$; $\mathrm{Ca}\left(\mathrm{NO}_{3}\right)_{2}, 0.01$; the $\mathrm{pH}$ was adjusted to 2.5 with $\mathrm{H}_{2} \mathrm{SO}_{4}$ and it was then autoclaved. Trace elements solution consisted of $\left(\mathrm{mg} \mathrm{l}^{-1}\right): \mathrm{FeCl}_{3} .6 \mathrm{H}_{2} \mathrm{O}, 11.0 ; \mathrm{CaSO}_{4} .5 \mathrm{H}_{2} \mathrm{O}, 0.5 ; \mathrm{HBO}_{3}, 2 \cdot 0$; $\mathrm{Na}_{2} \mathrm{MoO}_{4} \cdot 2 \mathrm{H}_{2} \mathrm{O}, 0.8 ; \mathrm{CoCl}_{2} \cdot 6 \mathrm{H}_{2} \mathrm{O}, 0.6 ; \mathrm{ZnSO}_{4} \cdot 7 \mathrm{H}_{2} \mathrm{O}, 0.9$; filter sterilized. One millilitte of trace elements solution was added to $100 \mathrm{ml}$ mineral salts solution and to this was added either $50 \mathrm{mM} \mathrm{K}_{2} \mathrm{~S}_{4} \mathrm{O}_{6}$ or $100 \mathrm{mM} \mathrm{FeSO}_{4}$; the final ply was adjusted to $2 \cdot 5$. Luria-Bertani medium was used as a complete medium and M9 minimal medium as a selective medium (Sambrook et al., 1989).

Cloning and genetic manipulations. A cosmid bank of the $T$. ferrooxidans genome (Ramesar, 1988) was transduced into the $E$. coli mutant BH5262 according to the method of Sambrook $e t a l$. (1989). Possible $g s h A$ - or tr $x A$-positive transfectants were identified by their ability to grow on minimal medium. Strain BH5262 is unable to grow on minimal medium lacking glutathione, whereas $\operatorname{Trx} \mathrm{A}^{+}$or $\mathrm{GshA}^{+}$colonies can ( $\operatorname{Lim}$ et al., 1986). Cosmids were isolated from positive colonies. Subclones of one of the $\mathrm{GshA}^{+}$cosmids were made and tested for the ability to complement E. coli $\mathrm{BH} 5262$.

DNA techniques, sequencing and analysis. Standard methods were used for plasmid preparation, restriction enzyme digests, gel electrophoresis, ligations and DNA-DNA hybridizations (Sambrook et al., 1989). Labelling of probes, hybridization and detection were carried out according to the digoxigenin-dUTP non-radioactive DNA labelling and detection kit (Boehringer
Mannheim). DNA sequencing was carticd out by the dideoxy chain-termination method (Sanger et al., 1977) using the Sequenase kit (vetsion 2.0) from United States Biochemical. The sequence of the $2.4 \mathrm{kbp} \mathrm{ClaI-BamHI}$ fragment shown in Fig. 2 was determined for both strands. The Genetics Computer Group (GCG) software package was used for sequence analysis (Devereux et al., 1984).

Complementation of the $E$. coli mutants for citrate synthase. Various plasmid constructs were tested for the ability to complement E. coli glt $A$ mutant MOB150 by streaking transformants onto M9 minimal medium (10 mM glucose). Strain MOB150 is unable to grow on minimal medium lacking glutamate, whereas Glt $\mathrm{A}^{+}$colonies can.

In vitro synthesis of gshA and g/tA. The synthesis of polypeptides from cosmid 5.1, plasmids pTHIOD, p'THIO28 and $\mathrm{pTHIO} 7$ and the vector $\mathrm{pBluescript} \mathrm{SK}$ was determined using the prokaryotic-DNA-directed transcription/translation kit, E. coli S30 system from Promega. Reactions were performed according to the manufacturer's specifications and the proteins were separated by SDS-PAGE using 5-20\% (w/v) gradient gels.

Analysis of transcripts. T. ferrooxidans total RNA was prepared from cultures grown on tetrathionate medium and E. coli total RNA was prepared from cultures grown on M9 minimal medium, by the method of Aiba et al. (1981). For DNA-RNA hybridizations, total RNA was separated on a $1.5 \%$ agarose gel containing $6 \%(\mathrm{v} / \mathrm{v})$ formaldehyde. The RNA was transferted to an Amersham Hybond $\mathrm{N}^{+}$membrane and hybridization and washes were carried out according to the protocol of the manufacturers. Labelling of probes was carried out with ${ }^{32} \mathrm{P}$ using a Random Primed DNA labelling kit (Boehringer Mannheim).

GSH assay. The fluorometric method described by Hissin \& Hilf (1976) was used to measure the endogenous GSH content of E. coli BH5262, E. coli BH5262(pTHIO7) and E. coli MC1061 cells, grown on M9 minimal medium with the necessary media supplements.

\section{RESULTS}

\section{Isolation and localization of the gshA gene}

E. coli BH5262 is a $\operatorname{tr} x A$ gsh $A$ double mutant which is unable to grow on minimal medium lacking glutathione whereas either $\mathrm{TrxA}^{+}$or $\mathrm{GshA}^{+}$colonies can ( $\mathrm{Lim}$ et al., 1986). Complementation of the gsh $A$ gene would enable the E. coli mutant to synthesize glutathione and permit growth on minimal medium. Transduction of the $T$. ferrooxidans genome cosmid library into E. coli BH5262 resulted in approximately 100 colonies that were able to grow on minimal media lacking glutathione. DNA was prepared from 16 of these colonies. These cosmids had several fragments in common and could be divided into two groups that appeared to contain overlapping pieces of two regions of the $T$. ferrooxidans chromosome. One of the groups of cosmids was found to permit growth of an $E$. coli met $A 46 \operatorname{tr} \times A$ mutant on minimal medium containing methionine sulfoxide and contained the thioredoxin gene (Powles et al., 1995). A representative from the other group of cosmids, cosmid 5.1, was chosen for further study.

A $5 \mathrm{kbp}$ HindIII fragment from cosmid 5.1 which complemented E. coli BH5262 was subcloned into the 


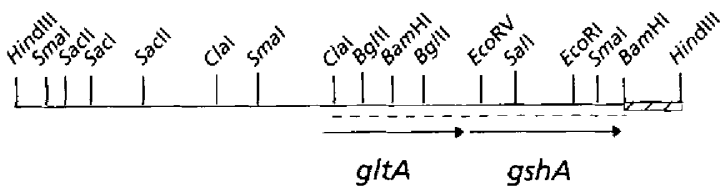

$\stackrel{+}{\longrightarrow}$
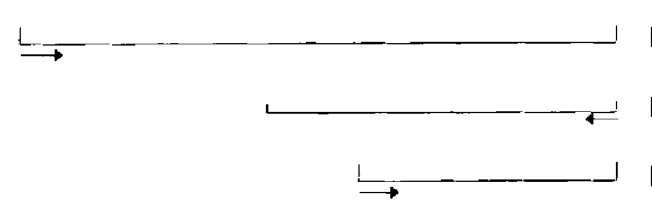

pTHIO7

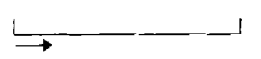

$\longleftarrow$
PTHIOD +

PTHIO6 ++

pTHוos

pTHIO28

PTHIO82
GshA $^{+}$GltA $^{+}$

+ Fig. 1. Restriction endonuclease map of plasmid PTHIOD and derivatives. The git $A$ and gshA genes are indicated by arrows. The dotted line represents the region of DNA sequenced from both strands. GshA or GltA $^{+}$activity indicates that the transformed plasmid was able to complement the $\gamma$ glutamylcysteine synthetase mutation of $E$. coli $\mathrm{BH} 5262$ or the citrate synthase mutation of $E$. coli MOB150, respectively. The arrows at the end of each plasmid indicate the direction of the lac promoter of the vector.

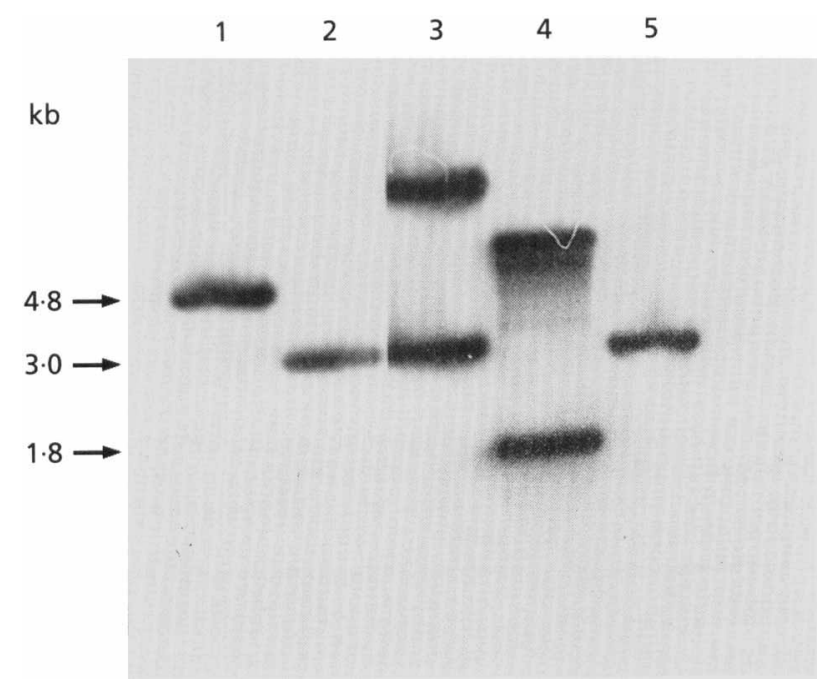

Fig. 2. Hybridization of labelled plasmid pTHIO7 to Smal digests of plasmid pTHIO7 (lane 1), plasmid pTHIOD (lane 2), cosmid 5.1 (lane 3 ) and $T$. ferrooxidans ATCC 33020 chromosomal DNA (lane 5) and a BamHI digest of cosmid 5.1 (lane 4).

vector pUCMB21 to give plasmid pTHIOD (Fig. 1). A restriction map of $\mathrm{p}^{\prime}$ THIOD was constructed, and smaller fragments were subcloned into vectors pUCBM20, pLCBM21 or pBluescript SK and tested for their ability to complement E. coli BH5262 for growth on minimal medium lacking glutathione (Fig. 1).

Confirmation of the source of the gsh $A$-complementing DNA was shown by hybridization of the labelied plasmid pTHIO7 to pTHIO7, PTHIOD, cosmid 5.1 and $T$. ferrooxidans ATCC 33020 chromosomal DNA digested with $S \mathrm{maI}$ (Fig. 2, lanes 1, 2, 3 and 5, respectively) and to cosmid 5.1 digested with BamHI (Fig. 2, lane 4). The $3.0 \mathrm{~kb} \mathrm{SmaI}$ fragment that is internal to the cloned $T$. ferrooxidans DNA present on pTHIOD (lane 2) corresponded exactly to an $S m a$ I fragment present on the $T$. ferrooxidans chromosome (lane 5) and cosmid 5.1 (lane 3). Similarly, the $1.8 \mathrm{~kb}$ BamHI fragment present on cosmid

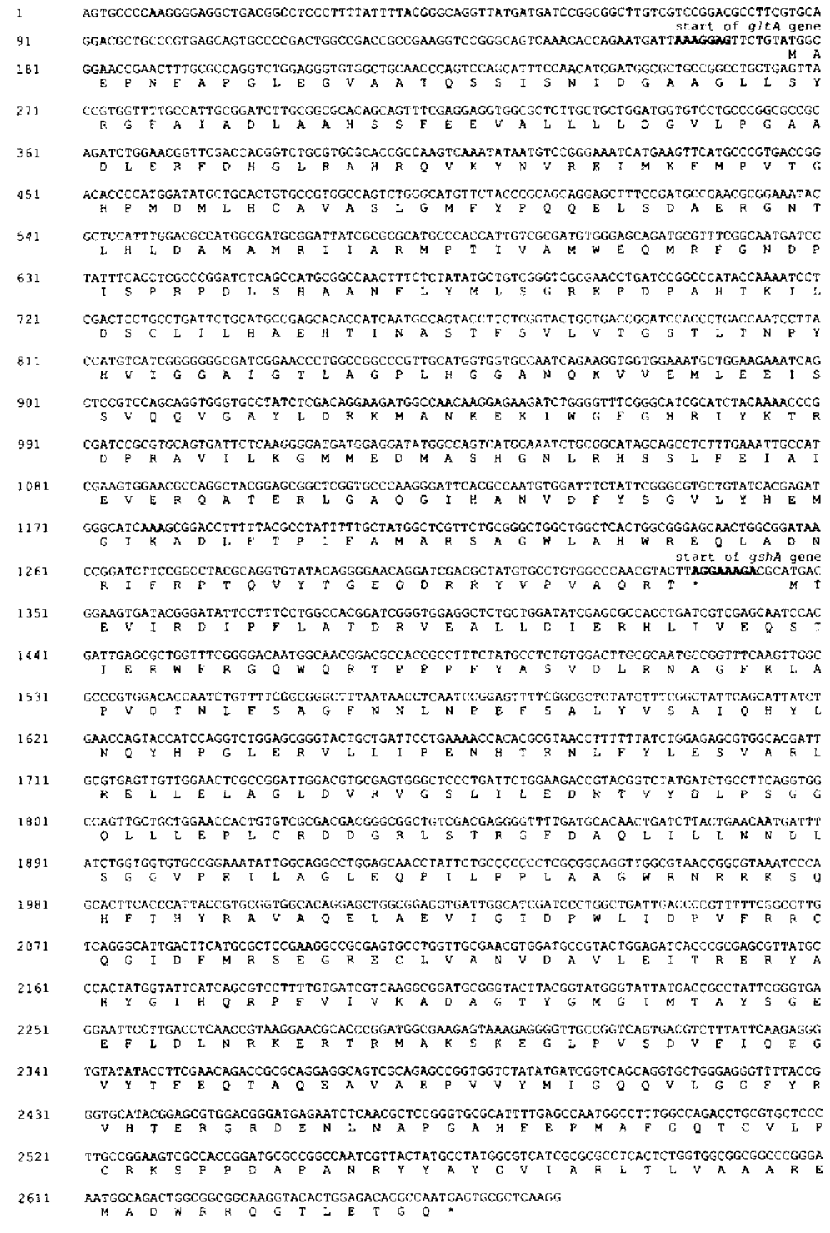

Fig. 3. Nucleotide sequence of the $2657 \mathrm{bp} \mathrm{Clal-BamHI}$ fragment and the deduced citrate synthase and $y$ glutamylcysteine synthetase amino acid sequences. Putative ribosome-binding sites are indicated in bold.

5.1 (lane 4) corresponded to the size predicted from the restriction endonuclease map. The hybridization signal of pTHIO7 at $4.8 \mathrm{~kb}$ (lane 1) corresponded to the linearized plasmid, as p THIO7 only contains a single $S \mathrm{maI}$ site. The 


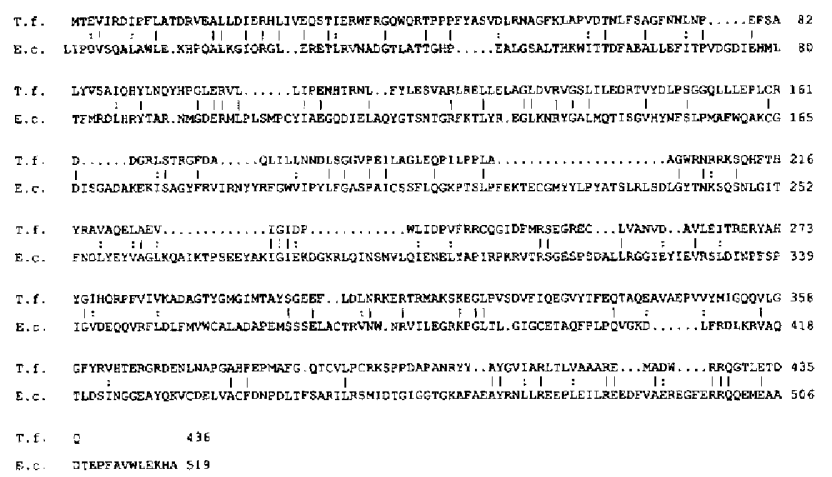

Fig. 4. Comparison of the amino acid sequences of the $T$. ferrooxidans (T. f) and E. coli (E. C) (GenBank/EMBL accession no. X03954) $\gamma$-glutamylcysteine synthetase proteins.

hybridization signals to the upper bands of cosmid 5.1 (lanes 3 and 4) corresponded to hybridization of the $S m a I-B a m H I$ flanking region joined to vector DNA. This result indicated that the source of the $3.0 \mathrm{~kb} S_{m a \mathrm{I}}$ insert was from the $T$. ferroxidans ATCC 33020 chromosome and that no rearrangements had occurred during cloning.

\section{Identification of GltA and GshA}

Analysis of the sequence from the $C l a I$ site to the $B a m H I$ site revealed two complete ORFs separated by 9 bp (Fig. 3). The first ORF is preceded by a strong ribosomebinding site and encodes a polypeptide of 386 amino acids, corresponding to a protein of $42.7 \mathrm{kDa}$. The predicted amino acid sequence was closely related to that of a number of citrate synthases (37\% identity and $59 \%$ similarity to E. coli; GenBank/EMBL accession no. J01619). The second ORF encodes a polypeptide of 436 amino acids, corresponding to a protein of $49 \cdot 3 \mathrm{kDa}$. The predicted amino acid sequence was matched against all sequences present in the GenBank and EMBL databases using the NCBI BLAST program. Weak but clear homology $(18 \%$ amino acid identity; Fig. 4) to the $\gamma$-glutamylcysteine synthetase gene of $E$. coli was detected. No clear homology to the other four $\gamma$-glutamylcysteine synthetases present in the databases was appatent.

Synthesis of proteins corresponding to the $T$. ferrooxidans $\gamma$-glutamylcysteine synthetase $(49 \cdot 3 \mathrm{kDa})$ and citrate synthase $(42.7 \mathrm{kDa})$ enzymes was confirmed using an E. coliderived in vitro transcription/translation system. A protein of approximately $49 \mathrm{kDa}$ was produced by cosmid 5.1 and plasmids p'THIOD and p'THIO7, but not by the vector pBluescript SK, plasmid pTHIO28 or the cosmid vector pHC79 (results not shown) (Fig. 5). Cosmid 5.1 and plasmids $\mathrm{p}$ THIOD and $\mathrm{p}$ THIO28 produced a protein of approximately $43 \mathrm{kDa}$, whilst the vectors pBluescript SK and cosmid $\mathrm{pHC} 79$ (tesults not shown) and plasmid p'THIO7 did not (Fig. 5).

\section{GSH assay}

Becausc of the low sequence homology and the difference in size between the $49 \mathrm{kDa}$ polypeptide and the E. coli $\gamma$ glutamylcysteine synthetase $(60 \mathrm{kDa})$, an assay for $\gamma$ -

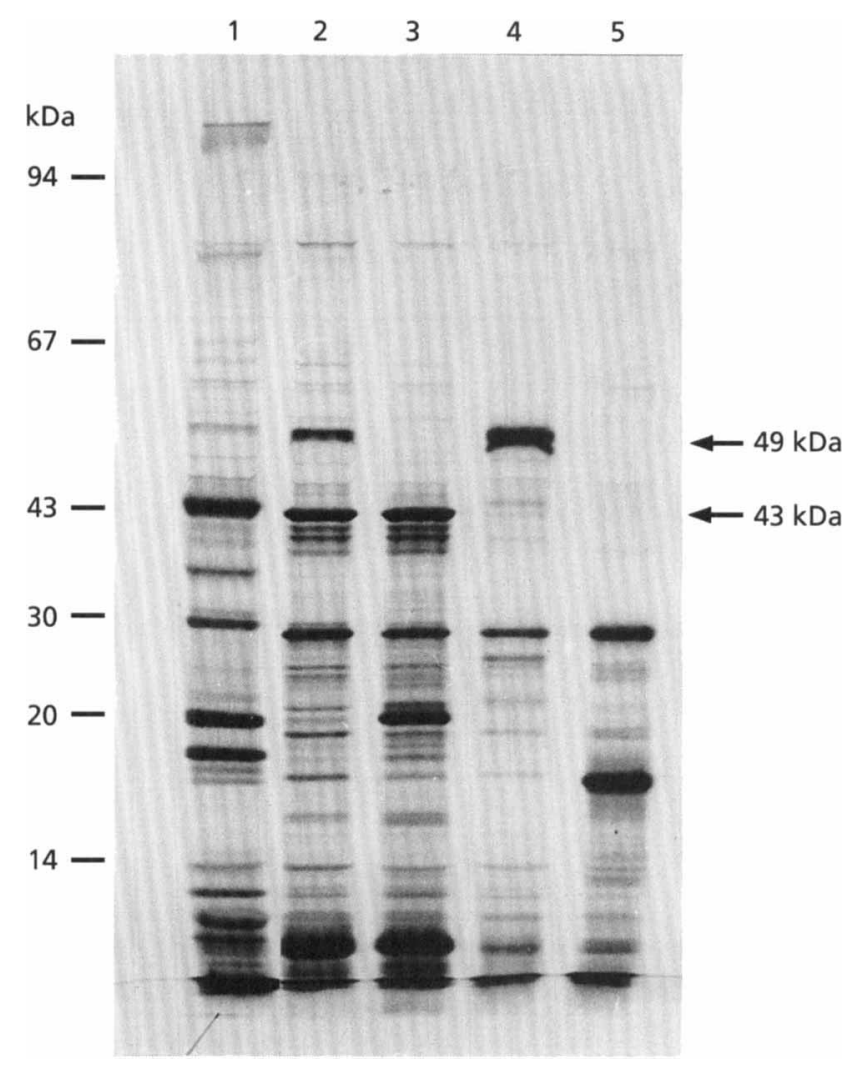

Fig. 5. SDS-PAGE analysis of proteins expressed from cosmid 5.1, plasmids pTHIOD, pTHIO28 and pTHIO7 and pBluescript SK (lanes $1-5$, respectively) using an $E$. coli-derived in vitro transcription/translation system.

glutamylcysteine synthetase activity was carried out. GSH was shown to react specifically with 0 -opthalaldehyde at $\mathrm{pH} 8.0$, yielding a highly fluorescent product that could be activated at $350 \mathrm{~nm}$ with an emission peak at $420 \mathrm{~nm}$ (Hissin \& Hilf, 1976). Concentrations of GSH in crude extracts of E. coli BH5262, BH5262(pTHIO7) and the parental strain E. coli MC1061 were compared. Extracts prepared from E. coli BH5262(pTHIO7) contained far higher levels of GSH [29.67 $\pm 3.06 \mathrm{nmol}$ GSH (mg protein $)^{-1}$ ] than extracts from $E$. coli BH5262 cells $\left[9 \cdot 00 \pm 1.73 \mathrm{nmol} \mathrm{GSH}(\mathrm{mg} \text { protein })^{-1}\right]$, and almost the same levels of GSH as extracts prepared from a wild-type E. coli strain MC1061 [31.67 $\pm 4.04 \mathrm{nmol}$ GSH (mg protein $\left.)^{-1}\right]$. This clearly indicates that $\gamma$-glutamylcysteine is produced by the cloned $T$. ferrooxidans gsh $A$ gene, which is then converted to GSH by the host glutathione synthetase $(g \operatorname{sh} B)$ gene.

\section{Complementation of $E$. coli gltA mutants}

Various plasmids thought to contain the T. ferrooxidans citrate synthase gene were tested for the ability to complement the glt $A$ phenotype of E. colistrain MOB150. Plasmid pMW264, which contains the Rickettsia prowazekii citrate synthase gene (Wood et al., 1987), was used as a positive control. Plasmids pMW264, p'THIO6, p'THIO28 and pTHIO82 enabled the E. coliglt $A$ mutant 


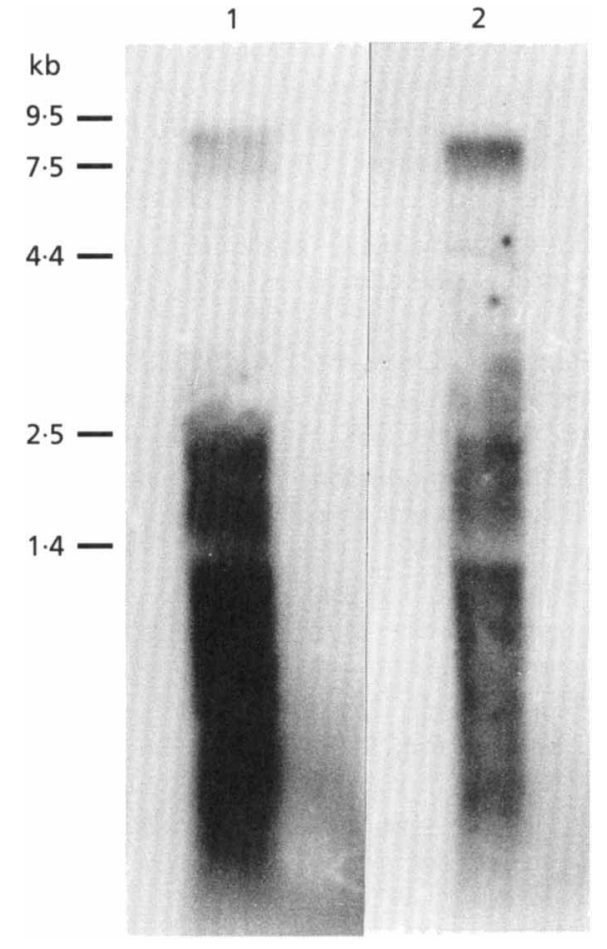

Fig. 6. Hybridization of a labelled BamHI-Smal fragment of pTHIO28 (lane 1) and a labelled BamHI-Sall fragment of pTHIO7 (lane 2), to total RNA prepared from $T$. ferrooxidans.

to grow on minimal medium, while the vector pBluescript did not. Cosmid 5.1 complemented E. coli MOB150 very weakly. As the glt $A$ gene in pTHIO28 and pTHIO82 lies in an opposite orientation with respect to the lac promoter, and both plasmids are able to complement E. coli MOB150, the cloned $T$. ferrooxidans glt $A$ gene appears to be expressed in E. coli from its own promoter.

\section{Transcript analysis}

To determine whether the citrate synthase and the $\gamma$ glutamylcysteine synthetase genes were part of an operon, total RNA isolated from T. ferrooxidans cells was examined by RNA-DNA hybridization. The transcripts were probed with the BamHI-SmaI fragment from pTHIO28 (specific to the glt $A$ gene) and the BamHI-SalI fragment from pTHIO7 (specific to the gsh $A$ gene). With both probes, a small quantity of transcript of about $9 \mathrm{~kb}$ and a transcript of $2.5 \mathrm{~kb}$ was obtained (Fig. 6), irrespective of which probe was used. No signal was obtained when either probe was hybridized to E. coli JM109 control mRNA (result not shown).

\section{DISCUSSION}

The redox potential in the environment of an ironoxidizing bacterium such as $T$. ferrooxidans is a function of the $\mathrm{Fe}^{3+} / \mathrm{Fe}^{2+}$ ratio. When ferrous iron is oxidized to ferric iron, the redox potential of the surrounding medium increases correspondingly and bacteria which grow in such an environment require the ability to maintain their cytoplasmic redox potential within certain limits. Ironoxidizing bacteria like $T$. ferrooxidans might therefore be expected to have a greater capacity for controlling their internal redox potential than most bacteria. Glutathione and thioredoxin are two molecules that play a role in the control of redox potential within a cell. It is interesting that transposon $\mathrm{Tn} 5467$, which is located on T. ferrooxidans plasmid $\mathrm{p}$ TF-FC2, has recently been shown to encode a functional glutaredoxin-like protein (Clennel et al., 1995) which might be expected to participate in internal redox control.

In spite of the low sequence homology to other $g s h A$ genes, there is evidence to indicate that the $g s h A$ gene of $T$. ferrooxidans has been isolated. The cloned gene from $T$. ferrooxidans was able to complement the E. coli gsh $A$ mutant for growth on minimal medium. Concentrations of GSH produced by the cloned gene in the E. coli gsh $A$ mutant were comparable to those of the wild-type E. coli strain, indicating the presence of a functional $\gamma$-glutamylcysteine synthetase. Furthermore, lack of homology between $\gamma$-glutamylcysteine synthetases is common, as with the exception of human and rat, $\gamma$-glutamylcysteine synthetases are generally poorly conserved.

Several pieces of evidence support the view that the $T$. ferrooxidans citrate synthase and $\gamma$-glutamylcysteine synthetase genes are transcriptionally linked. DNA-RNA hybridization experiments indicated similar-sized transcription products irrespective of whether the glt $A$ or the $g s h A$ gene was used as a probe. Furthermore, the $g s h A$ gene does not appear to be transcribed from its own promoter in $E$. coli, as subclones in which the gsh $A$ gene is transcribed in the opposite orientation to the lac promoter were unable to complement the $g s h A$ mutation of E. coli BH5262. 'The citrate synthase gene, however, was able to complement glt $A$ mutant $E$. coli MOB150, irrespective of its orientation to the lac promoter. These results suggest that the $g s h A$ gene is transcribed from a promoter upstream of the citrate synthase gene. In addition, the two genes ate separated by only $9 \mathrm{bp}$, which is frequently a feature of genes that are transcriptionally coupled. It has recently been discovered that in $T$. ferrooxidans ATCC 33020 the genes for lipoamide dehydrogenase $(l p d)$ and pyruvate dehydrogenase (ace $E$, ace $F$ ) lie immediately upstream of the git $A$ gene for citrate synthase (R. Powles, unpublished data). The $9 \mathrm{~kb}$ transcript visible in the RNA preparation from $T$. ferrooxidans (Fig. 6, lanes 1 and 2) also hybridizes to a probe prepared from the region upstream of the glt $A$ gene (unpublished). Transcriptional linkage of the aceE, aceF, lpd and glt $A$ genes is not unexpected since the enzymes they encode are all involved in the transfer of an acetate group to oxaloacetate during the biosynthesis of citrate. However, the teason for the linkage between the glt $A$ and $g s h A$ genes is unclear.

The $\gamma$-glutamylcysteine synthetases studied to date differ widely in amino acid sequence and structure. The mammalian proteins are composed of two subunits 
whereas the bacterial proteins (E. coli and P. mirabilis) are composed of a single subunit. The $T$. ferrooxidans protein also consists of a single subunit, of $49 \mathrm{kDa}$, which is considerably smaller than the $60 \mathrm{kDa}$ and $64 \mathrm{kDa}$ proteins of $E$. coli and $P$. mirabilis, respectively. The two mammalian $\gamma$-glutamylcysteine synthetases (tat and human) are very homologous ( $94 \%$ identity), and clearly related to that of Saccharomyces cerevisiae ( $45-46 \%$ identity). However, the amino acid sequences of the $\gamma$-glutamylcysteine synthetases of A. thaliana, T. ferrooxidans and E. coli are poorly related to each other and also to the rat, human and yeast enzymes (15-18\% identity). The location of the gene for glutathione synthetase, the second step in glutathione synthesis, is still unknown.

\section{ACKNOWLEDGEMENTS}

We thank James Fuchs for E. coli strain BH5262, David $O$. Wood for E. coli strain MOB150 and plasmid pNW264 and Di James for assistance with DNA sequencing. This work was supported by grants from the Foundation for Research Development and Gencor (South Africa).

\section{REFERENCES}

Aiba, H., Adhaya, S. \& de Crombrugge, B. (1981). Evidence for two functional gal promoters in intact E. coli cells. $J$ Bial Chem 256, 11905-11910.

Clennel, A.-M., Johnston, B. \& Rawlings, D. E. (1995). Structure and function of $\operatorname{Tn} 5467$, a $\operatorname{Tn} 21$-like transposon located on the Thiobacillus ferrooxidans broad-host-range plasmid pTF-FC2. Appl Environ Microbiol 61, 4223-4229.

Dennda, G. \& Kula, M.-R. (1986). Purification and evaluation of the glutathione-synthesizing enzymes of Candida boidinis for cell-free synthesis of gilutathione. J Biotechnol 4, 143-158.

Devereux, J., Haeberli, P. \& Smithies, O. (1984). A comprehensive set of sequence analysis programs for the VAX. Nucleic Acids Res $12,387-395$.

Hell, R. \& Bergmann, L. (1990). $\gamma$-Glutamylcysteine synthetase in higher plants: caralytic properties and subcellular localization. Planta 180, 603-612.

Hissin, P. J. \& Hilf, R. (1976). A fluorometric method for determination of oxidized and reduced glutathione in tissues. Anal Biocbem 74, 214.
Huang, C.-S., Moore, W. R. \& Meister, A. (1988). On the active site thiol of $\gamma$-glutamylcysteine synthetase: relationships to catalysis, inhibition, and regulation. Proc Nall Acad Sci USA 85, 2464-2468.

Huang, C. S., Anderson, M. E. \& Meister, A. (1993). Amino acid sequence and funcrion of the light subunit of rat kidney gammaglutamylcysteine synthetase. I Biol Chem 268, 20578-20583.

Kumagai, H., Nakayama, R. \& Tochikura, T. (1982), y-Glutamylcysteine synthetase from Proteus mirabilis. Agric Biol Chem 46 $1301-1309$.

Lim, C.-J., Gleason, F. K. \& Fuchs, J. A. (1986). Cloning, expression and characterization of the Anabaena thioredoxin gene is Eschericbia coli. J Bacteriol 168, 1258-1264.

Lindström, E. B., Gunneriusson, E. \& Tuovinen, O. H. (1992). Bacterial oxidation of refractory sulfide ores for gold recovery. Crit Rev Biotechnol 12, 133-155.

May, M. J. \& Leaver, C. J. (1994). Arabidopsis thaliana $\gamma$-glutamylcysteine synthetase is structurally unrelated to mammalian, yeast, and Escherichia coli homologs. Proc Natl Acad Soi USA 91, 10059-10063.

Meister, A. \& Anderson, M. E. (1983). Glutathione. Annu Rev Biochem 52, 711-760.

Powles, R. E., Deane, S. M. \& Rawlings, D. E. (1995). Molecular and genetic analysis of a thioredoxin gene from Tbiobacillus ferrooxidans. Microbiology 141, 2175-2181.

Ramesar, R. S. (1988). Developmental genetic studies on Tbiobacillus ferroxidans. PhD thesis, University of Cape Town, South Africa.

Richman, P. G. \& Meister, A. (1975). Regulation of $\gamma$-glutamylcysteine synthetase by nonallosteric feedback inhibition by glutathione. J Biol Chem 250, 1422-1426.

Sambrook, J., Fritsch, E. F. \& Maniatis, T. (1989). Molecular Cloning: a Laboratory Manual, 2nd edn. Cold Spring Harbor, NY: Cold Spring Harbor Laboratory.

Sanger, F., Nicklen, S. \& Coulson, A. R. (1977). DNA scquencing with chain-terminating inhibitors. Proc Natl Acad Soi USA 74, 3650-3654.

Seelig, G. F., Simondsen, R. P. \& Meister, A. (1984). Reversible dissociation of $\gamma$-glutamylcysteine synthetase into two subunits. $J$ Biol Chem 259, 9345-9347.

Wood, D. O., Williamson, L. R., Winkler, H. H. \& Krause, D.C. (1987). Nucleotide sequence of the Rickettsia prowazekii citrate synthase gene. J Bacteriol 169, 3564-3572.

Received 29 January 1996; revised 18 April 1996; accepted 7 May 1996. 